Dialectologia 23 (2019), 213-233.

ISSN: 2013-2247

Received 19 October 2017.

Accepted 19 May 2018.

\title{
EXAMINING THE DYNAMICS OF INTERACTION IN AN ARAB SPEECH COMMUNITY IN IRAN: A SOCIOLINGUISTIC ETHNOGRAPHY
}

\author{
Seyyed Hatam TAMIMI SA'D \\ Purdue University, USA* \\ stamimis@purdue.edu
}

\begin{abstract}
The current study explores the linguistic interactions of Iranian Arabs by taking into account such factors and concepts as interlocutor power, solidarity, politeness and impoliteness and other variables including gender, age, kinship and others. It attempts to delineate what constitutes polite as well as impolite linguistic behavior in light of the hierarchy of relations which is highly characteristic of the Arab society, culture and language. The study is a sociolinguistic ethnography carried out in a rural mono-ethnic Arab community in southwestern Iran. It is argued that linguistic interactions in Arab speech communities fall under the remarked influence of biological variables including age, sex and kinship, cultural factors such as religious affiliation and historical background, as well as linguistic aspects like the highly formulaic language employed. This complicated network of interwoven interactions creates a special type of dynamics. Interacting and participating in such a twisted linguistic setting becomes increasingly difficult particularly for 'linguistic newcomers or outsiders' such as young children and foreigners. It is concluded that, without a thorough awareness of the role of most of the above-mentioned variables, breakdown in communication will be most probably inevitable. In line with previous research, the analysis verifies the multifaceted nature of identity construction which is found to be the joint product of the dynamics of power relations, social interactions and linguistic structures. The study highlights the significant role played by ethnicity, culture, gender and religious affiliations.
\end{abstract}

\section{Keywords}

Arabic, hierarchy, impoliteness, interaction, politeness, power, speech community

\footnotetext{
* Beering Hall, 100 N, University Street, West Lafayette, IN 47907, USA.
} 


\section{EXAMINADO LAS DINÁMICAS DE INTERACCIÓN EN LA COMUNIDAD DE HABLA ÁRABAE EN IRAN: UNA SOCIOLINGÜÍSTICA ETNOGRÁFICA}

\section{Resumen}

Este estudio explora las interacciones lingüísticas de los árabes iraníes teniendo en cuenta factores y conceptos como el poder de los interlocutores, la solidaridad, la cortesía y la descortesía y las variables, género, edad, parentesco y otras. Intenta delinear lo que constituye tanto un comportamiento lingüístico cortés como descortés a la luz de la jerarquía de relaciones que son altamente representativas de la sociedad, la cultura y el idioma árabes. Se trata de una estudio de etnografía sociolingüística efectuada en una comunidad árabe monoétnica rural en el suroeste de Irán. Se considera que las interacciones lingüísticas en las comunidades de habla árabes están influenciadas por variables biológicas como la edad, el sexo y el parentesco, factores culturales como la afiliación religiosa y el trasfondo histórico, así como aspectos lingüísticos como el lenguaje altamente formulaico empleado. Esta red complicada de interacciones entrelazadas crea una dinámica especial. Interactuar y participar en un entorno lingüístico tan enroscado se vuelve cada vez más difícil, especialmente para los "recién llegados o forasteros lingüísticos", como niños y extranjeros. Se concluye que, sin un conocimiento profundo del rol de la mayoría de las variables mencionadas anteriormente, la interrupción de la comunicación será probablemente inevitable. En línea con investigaciones anteriores, el análisis verifica la naturaleza multifacética de la construcción de identidad, que es el producto conjunto de la dinámica de las relaciones de poder, las interacciones sociales y las estructuras lingüísticas. El estudio destaca el importante papel desempeñado por el origen étnico, la cultura, el género y las afiliaciones religiosas.

\section{Palabras clave}

Árabe, jerarquía, descortesía, interacción, cortesía, poder, discurso de la comunidad.

\section{Introduction}

Communication does not take place in a vacuum. It occurs in society, and, therefore, it is contextualized; that is, socially constructed and enacted. And since a multitude of variables exist in every social context, then language use is influenced by a variety of factors. As insights from fields as diverse as linguistics, sociology, anthropology and cultural studies continue to reveal the subtleties in human interactions, sociolinguists have also given credit to the significant role that various factors and variables such as the interactants' age, sex, social power, social distance, 
ethnicity, amongst others, play in the shaping, directing and maintaining of human communication. Johnstone (2008), for instance, holds that power and solidarity are inherent variables of communication which are always at play.

The present study aims to provide explanations to account for the dynamics of interaction in an Arab speech community in Iran. The justification for this research lies in the fact that, firstly, Arab speech communities are historically, sociolinguistically, sociologically and sociopolitically rich sites and, secondly, they are mostly underresearched. Therefore, hopefully, researching such areas is expected to yield useful insights into the subtleties of interactions of minorities.

\section{Theoretical Background}

In spite of the significance and contribution of non-verbal behavior, language is, most probably, the tool that is used the most frequently by human beings to communicate verbally with each other. Language both shapes and is shaped by our worldviews. It is both a means of expressing our attitudes and a reflection of our own attitudes, beliefs and views. Language use is under the constant impact of a number of linguistic, social and individual factors. These factors constitute age, sex, power and social hierarchy (Wardhaugh 2006). To set an example of how language functions in society, consider Al-Ali's (2006) study. Adopting Critical Discourse Analysis (CDA) and genre analysis approaches, Al-Ali (2006) investigated the issue of dominance and power as exercised in Jordanian Arabic wedding invitations. Al-Ali's analysis was indicative of the influence of kinship, religion and paternalism on most aspects of life in the Jordanian society.

Arab speech communities are contexts which are rich from various aspects. They can serve as potential areas of sociological, anthropological and linguistic research which is most likely to reveal significant facts regarding various social phenomena. These communities are, however, absent from the sociolinguistic research arena in a way that, to the researcher's best knowledge, no study has been carried out with the aim of uncovering the discursive practices, conventions and interactions in Arab speech 
communities in Iran although such studies abound in Arab countries (e.g., Al-Ali 2006). Pennycook (2009) asserts that the relationship between language and power and the way in which this relationship is modified by factors such as gender and race has not been carefully examined.

The objective of the present study is to uncover the fundamental features of linguistic interactions in an Arab speech community through a discussion of the major variables that contribute to the shape and configuration of communication. It is hoped that scrutinizing these interactions will reveal certain aspects of interaction that might not be characteristic of interactions of other speech communities. This will, in turn, assist in cross-cultural understanding and communication.

\section{Method}

\subsection{The Study}

The present study is ethnography. Far from being experimental and quantitative, Hymes (2004) argues, ethnographic research is systematic, comprehensive and topicoriented and addresses the study of people, their culture and their role relationships in situated social contexts. Ethnographic research is characterized by 'thick description'. This is defined as

a description inscribed in an ethnographic account conveying a quasi-insider's understanding of how members of the group communicate and interact with one another, what they believe and value, how they define and solve common problems, how they construct and apply knowledge, and how they accomplish other meaningful communal activities (Smart 2012: 149).

Liddicoat (2011: 844) posited that ethnography is "a way of seeing direct experience of lived reality as a text for interpretation". The data collection tools utilized in ethnographic research include narrative description and participant observation. The 
current study benefited from the latter data collection measure (i.e. participant observation) which necessitates the researcher being the author him/herself.

\subsection{Setting}

The current study was done in Khuzestan, a province in southwestern Iran. Officially called the Islamic Republic of Iran and bounded to the north by Azerbaijan, Armenia, Turkmenistan, and the Caspian Sea, to the east by Pakistan and Afghanistan, to the south by the Persian Gulf and the Gulf of Oman, and to the west by Turkey and Iraq (Britannica 2014), Iran is located in southwestern Asia composed of thirty-one provinces. Iran has adopted Farsi or Persian as its official language. However, there are a large number of other languages spoken by millions of ethnic and religious groups including (alphabetically ordered) Arabic, Baluchi, Kurdish, Turkish and Turkmen. According to some statistics, Arabs constitute a community of 1.5 million people ( $2 \%$ of the whole population of Iran). Iranian Arabs live in the provinces of Khorasan, Fars and Khuzestan, with Khuzestan hosting the vast majority of Arabs in Iran (Wikipedia 2014). The map of the province of Khuzestan is provided in Figure 1.

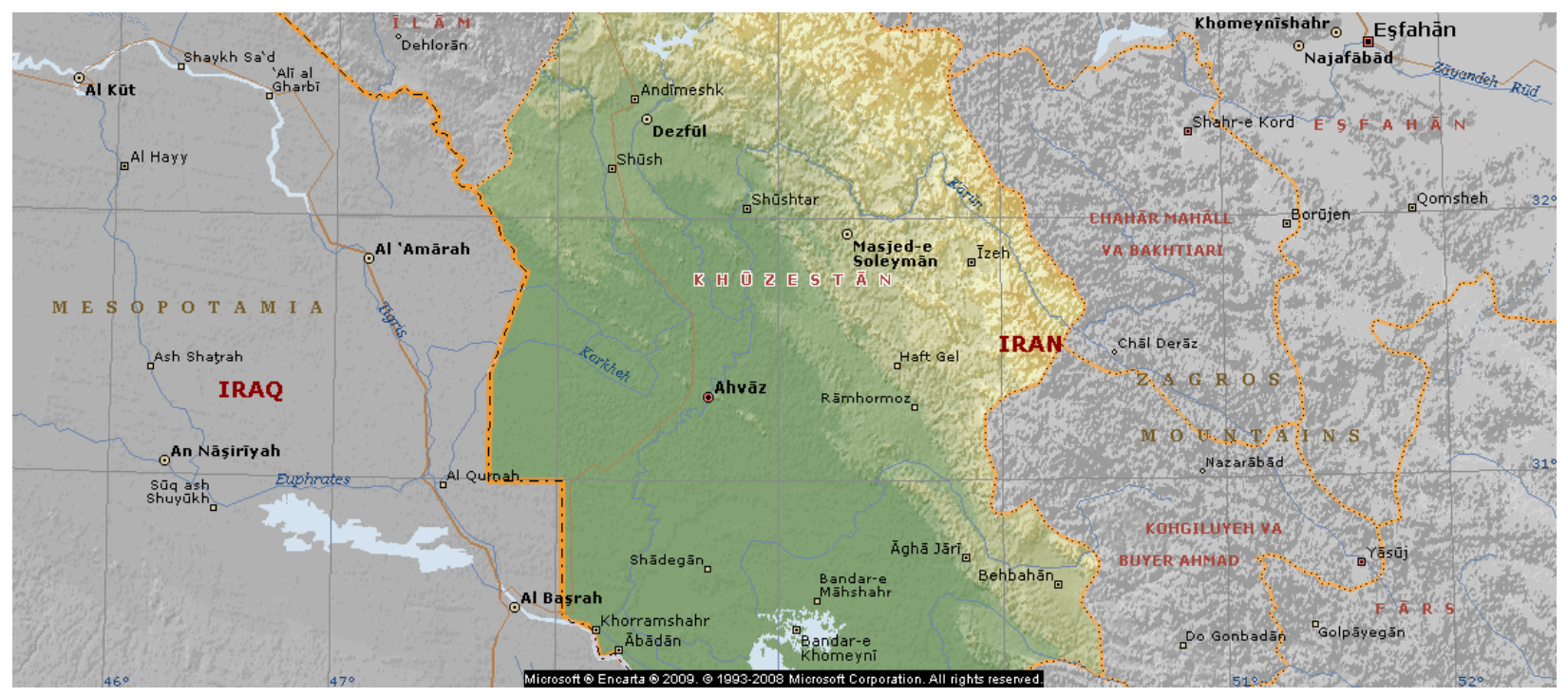

Figure 1. The map of the Province of Khuzestan (source: Microsoft ${ }^{\circledR}$ Encarta ${ }^{\circledR}$ 2009. (C) 1993-2008 Microsoft Corporation. All rights reserved). 


\subsection{Instruments}

Participant observations were the primary data collection tool utilized in this study. In participant observation, the observation is conducted by an individual who is $\mathrm{him} /$ herself a member of the community in which the observation is conducted. Jaffe (2014: 214) believes that "[...] participant observation is the hallmark of the ethnographic process". She further remarks that participant observation is "a way of capturing the dynamic, multilayered, and shifting nature of context" (Jaffe 2014: 215); original italics).

\subsection{Procedure}

The study was carried out on a three-year period from 2012 to 2015. Observations of the interlocutors were carried out in which their interactions were assessed in terms of their culture and the components which that culture was built around. For instance, cases of polite/impolite behavior, effect of hierarchy on interactions through age, sex, kinship, religious beliefs, rituals, power and solidarity were closely attended to. The researcher's own interpretation of these variables and their role in directing the interlocutors' interactions in this Arab speech community is presented here. This interpretation is based upon the theories discussed below (e.g., Politeness Theory, Audience Design, etc.). The study is therefore qualitative.

\section{Results and Discussion}

This part starts off elaborating on some of the most salient features and factors that are prevalent in interactions among Arabs in Iran. The sections here include discussions of the following subjects: social hierarchy, age, sex and gender, kinship, religion, power, politeness and impoliteness, etc. The discussion is informed by previous similar research and theorizing including Politeness Theory, Audience Design, Phatic Communion, etc. 


\subsection{Hierarchical Society}

The Arabic society is extremely hierarchical. This hierarchy can be seen in a variety of aspects of life, particularly in social rituals: marriages and wedding parties, mourning, burial and other religious ceremonies and rituals, and norms. It is essential that all language users, particularly adults, be aware of this hierarchy which manifests itself very clearly in language use since a huge portion of language usage hinges upon the appropriate understanding of this hierarchical system. It is expected, for instance, that every member of a tribe, clan or family take notice of the importance of the addressee's age and take part in linguistic interactions by adhering to the specific rules of discourse already specified. Older interlocutors are to go on speaking uninterrupted while younger interactants are required to keep silent unless they are allowed to speak up. The specification of such discursive regulations, rules and codes of practice has been done over the history of that speech community. But how can this statement be proved right? Proof can be provided through an analysis of the most common themes found in the highly traditional narratives that are most often presented in family gatherings, rituals or even among children. These narratives have been weaved into the culture of the Arab community throughout a long history of discursive development. The most popular themes of stories, fables and anecdotes that are often narrated in such communities revolve around moral, principal and hardship issues of life. The shared themes of these fictions aim to produce and preserve cultural knowledge transmitted over generations (Beckner et al. 2009: 3). This cultural knowledge is said to hinge upon 'cooperative activity' or 'joint action', the origin of which is believed to be 'shared cognition' (p. 3). In the sections that follow, some of the most prevalent factors that affect interaction dynamics in an Arab community are presented and discussed.

\subsection{Age}

Of considerable significance in linguistic interactions in Arab speech communities is the factor of biological age which is closely linked to wisdom and sagacity. Older 
people are always more powerful than younger ones. Age confers the elderly a type of power that rarely are other variables able to bestow. Age constitutes one of the frames upon which group identity is constructed (Schilling-Estes 2004). It is most often argued that interlocutors position themselves. Simply put, the factor of age states that: the older, the more powerful.

\subsection{Sex, Gender and Gendered Discourse}

Like age, sex plays an extremely important role in the linguistic interactions of Arabs. Men, boys, and almost whatever male, even objects such as the moon, utensils like plates and glass, are powerful in nature and have more control over whatever feminine, from women and girls to the sun, spoons and table cloth. Men are socially allowed, and more specifically expected, to speak up in public. They must not be interrupted, and even if they must be, it must not be done by women. Women are approved of when they keep silent and obedient. In the Arab-Muslim society, the 'silence-is-gold' rule is mostly applicable to and mainly reminiscent of women and girls. Studies by the Moroccan feminist writer, sociologist and anthropologist Fatima Mernissi confirm our assumptions here. With regard to gender in Muslim communities, Mernissi (2005) argues that all discussions of gender in Islam must be primarily held in light of the Prophet's married life. Mernissi (2005: 94) goes further to explain that "entire Muslim social structure can be seen as an attack on, and a defense against, the disruptive power of female sexuality". She also holds that Islam endorses an anti-'female sexuality', if not an anti-'female', policy toward women. Similarly, Christmann (2009) confirms that previous attempts have not succeeded in revaluing the women's status in the ArabMuslim world.

The Arab speech community regards the female gender as weak and powerless. Women's way of speaking is also considered feeble and it is, therefore, eschewed by males. This avoidance is explained and justified on the grounds that males tend to think in terms of 'masculinity' which is the norm to them. It is interesting, and equally ironic, that Arab women attribute a saying (Arabic Hadith) to the Prophet Muhammed which says: Consult with women but do not accept their opinions. Arab women of the speech 
community in the present study seem to have agreed to the discursive subjugation they have been exposed to throughout a long history of male-led suppression and dominance. It can be hypothesized that this is indicative of the use of language between man and woman in the Arab community for the sake of interaction but not transaction with the former referring to establishing and maintaining social relations and the latter pertaining information exchange with the purpose of social or individual function. Malinowski's (1999 [1926]) theory of Phatic Communion is a theory that might well apply here. According to this theory, interactions can be directed in the path of establishing social relations primarily for the sake of fostering solidarity and not solely for purposes of information exchange. The domination of the male over the female by which the Arab speech community is characterized has been used by many feminist writers to refer to "the social system of masculine domination over women" (Pilcher \& Whelehan 2004: 93). Pilcher \& Whelehan (2004) posit that such domination is characteristic of patriarchic societies and is a result of gender inequality. Similarly, Nigosian (2004) asserts that millions of Muslim women have attempted to redress these inequalities by forming relevant groups, leagues, associations, and organizations.

Differences between Arab male and female speakers' speech can be examined in light of Speech Act theory as well (Austin 1962). This theory puts forth the idea that speech is a type of action, hence the term 'speech act', which is enacted through requesting, apologizing, refusing, complaining and so forth. Arguably, the different social roles of each gender in the Arab speech community under examination here have prompted Arab male and female individuals to speak differently. Convincing and confirming evidence has been produced by the numerous studies that have been carried out either in Arab contexts or with Arab interlocutors (e.g., Assiri 2012; Bataineh \& Bataineh 2006). Our observations demonstrate that Arab women are more accepting of and compliant with the faults, either committed by them or falsely attributed to and imposed upon them, than men. In fact, rarely did men admitted to having committed a wrongdoing. In this regard, in a study of the differences between Arab males and females in apologizing, Assiri (2012), for instance, found that Arab female speakers intensified their apology strategies, promised to redress the wrong and assumed responsibility for it more frequently than men did. To set another example, Bataineh \& 
Bataineh's (2006) study of Jordanian Arab male and female speakers' apology strategies indicated that females tended to eschew discussing the offense committed. Almost the same phenomenon was observed here: compared to men, Arab women were more inclined to either shift toward silence when blamed by their male peers (husbands, brothers or fathers) or to apologize, sometimes even for offenses for which they were not responsible. This finding might have been historically foregrounded such that the discursive phenomenon prevalent in the Arab community under examination has been in practice for hundreds of years. Thorne (1993, as cited in Cameron 2005: 24) predicts that gender separation results from age separation: "[...] where age separation is present, gender separation is more likely to occur". According to Cameron (2005), gender separation starts in childhood as early as the age of three and four. Cameron goes on further to hypothesize that the outcome of such separation is distance. This position seems to be totally in keeping with the results of the present study. The results showed that Arabs dissented contacts between the two genders for what they perceive as 'ethical and moral' reasons. Holmes (1999) makes a distinction between two groups of members in a community: core members and peripheral members. These two terms are suggestive; that is to say, the former refers to the more powerful and the latter to the less powerful members. In the Arab community under investigation in the current study, the two terms are readily applicable to the male and female members, respectively. While the dominant male members view themselves as privileged to initiate and conclude conversations, females are denied this right. The interesting finding of the current study is that the female members also consent to such denial of right and it seems that this discursive act has been practiced over prolonged periods of time and has intertwined with the sociocultural beliefs of the Arab community.

Another issue of significance in the Arab speech community is the fact that most often, particularly when it comes to the role of gender, it is the male toward whom the role of the female is defined. This attitude toward what constitutes normality is reflected in a statement by Matsuda (1991, as cited in Wardhaugh 2006: 47): "When ... parties are in a relationship of domination and subordination we tend to say that the dominant is normal, and the subordinate is different from normal". It can be deduced that what determines the role of both genders is the degree of their power, influence 
and domination. The amount of power has been certainly determined historically over prolonged periods of what might be referred to as 'masculinization'.

To conclude this section, although sex and gender are two distinct notions, with the former being conceived as biological and the latter as a socially entrenched concept, the two concepts seem to work in tandem in the Arab speech community under investigation. The mutual relationship between sex and gender is built up in the following way: women, by virtue of their sex, are supposed to be 'different' from the 'norm' and therefore are to have their own discourse. The gendered discourse just mentioned is built upon women's sex.

\subsection{Kinship, Race and Ethnicity}

Kinship is of considerable significance in Arab communities. The reasons for this significance are easy to understand: Arab communities are highly tribal, comprising and causing numerous webs of interaction among individuals. Kinship terms abound in Arab communities. Kinship has produced a variety of terms used to address relatives as well as non-relatives in Arab speech communities. Undoubted, a kinship system brings about images of ethnicity. Toni Morrison has been cited as saying "When you know someone's race, you know nothing [about her]" (Weiss \& Wodak 2003). This statement, however, does not seem to be completely true of the Arab speech community in which race determines and directs a large proportion of the interactions. Race is what Arabs expressed pride when it comes to comparisons between their race and others'.

\subsection{Religious Affiliation}

A large number of factors and elements fall under the rubric of religion: The Koran (also the Qur'an), Hadith (i.e., the Prophet Muhammed's holy sayings), Sunna (i.e., the practice and act of the Prophet), and religious practices such as morning, afternoon or evening prayers. Al-Ali (2006) holds that man's power and control over woman in Arabic societies emanates from the Koranic teachings. The Koran enjoins upon Muslims teachings which promote male dominance and assign certain social and individual 
duties, obligations and commitments upon them. The impact of the religious teachings is so profound that Al-Ali (2006: 710) states, "Religious power, as the first socio-cultural constraint, is particularly emphasized among Moslems because respect for religion is carefully ingrained in children and religious prospects tend to regulate Moslems' social lives". Therefore, in order to grasp a profound understanding of the role of religious beliefs in the Arab community, one must refer to the teachings that children are exposed to and receive in early childhood.

To situate and depict the current status of Muslim women, one needs to capture their picture on a longitudinal axis. Anwar (2004: 375) states that "Although women have achieved important advances in the public sphere, the idealization of the proper Muslim woman as a mother and a wife has never died". It is clear that the consequences of assigning such roles (i.e. mother and wife) to the female gender reflect and manifest themselves in numerous aspects of life and in various settings enclosed within the walls of the house. First, it creates a distance between the two genders (Cameron 2005) which prohibits socialization between them and therefore prevents solidarity. Second, and perhaps more importantly, it serves to subjugate women, therefore justifying, if not legitimatizing, males' oppressive behavior.

\subsection{Formulaic Language}

Linguistic interactions in the Arabic used by Iranian Arabs are highly formulaic particularly when these interactions include speech acts such as greetings, congratulating, extending condolences, inviting, thanking, complimenting and responding to compliments. By formulaic is meant fixed; that is to say, language which consists of fixed or semi-fixed expressions. In a sense, to some extent, the performance of almost all speech acts can be accomplished through formulaic language. Diverging from this formulaicity would not, most probably, be viewed as innovation, but as uncalled-for violation which would, again most probably, transcend the linguistic norms and step into the rituals and traditions. This notwithstanding, formulaic language can be manipulated in joking situations in which the purpose is to establish solidarity by creating a less formal atmosphere. 
Formulaic language is a 'two-edged sword' in that it is easy to master but also risky to use as simple, unintentional mistakes would, in all likelihood, cause the speaker severe embarrassment and, at times, harsh criticism mainly on the part of relatives or friends. This accounts for the major and main proportion of many Arab speakers' shyness and their consequent refrain from attending discoursal interactions often observed among Arab children who are often not fluent enough in the formulaic language of interactions and are afraid of unintentionally breaching the strict linguistic 'code'.

Language exchanges, such as greetings, extending condolences/congratulations or paying or responding to compliments which are widely used in rituals and ceremonies in Arab speech communities, are not expected to be left unanswered or incomplete but must be attended and replied to closely and properly. The highly formulaic nature of such interactions is so dominant in Arab communities that it is often very difficult for some to comply with such use of language. Therefore, some interlocutors and members of an Arab community may wish to avoid participating in such formulaicity-driven interactions, simply fearing failure in those interactions. On the contrary, participating in such interactions with success brings the interlocutor praise and commendation among the family or tribe members. In fact, as Dickinson (2013) argued, one's in-group identity is constructed and reconstructed through the mastery of the formulaic language.

\subsection{Arab Community of Practice and Speech Communities}

Eckert \& McConnell-Ginet (1992, as cited in Davies 2005: 558) define a Community of Practice (CofP) as "an aggregate of people who come together around mutual engagement in an endeavor. Ways of doing things, ways of talking, beliefs, values, power relations in short practices emerge in the course of this mutual endeavor". Regarding CofP, Davies (2005: 557) further assumes that, "Communities of practice characterize membership as being created and maintained through social practices (linguistic or otherwise) at a local level, rather than global categories being imposed on individuals". Simply put, 'Practice' is "a way of doing things, as grounded in and shared by a community" (Eckert \& Wenger 2005: 583). 
On the other hand, a 'speech community', also called language community, is not dissimilar to a CofP in definition: "a social aggregate within which language is used" (Irving 2009: 1019). Apart from the fact that whether a 'community' should be construed as an abstraction or a real describable object in the world is controversial issue, in the present study, a community is simply taken to mean an aggregate of people with the same linguistic, ethnic and cultural background. Such a definition paves the way for a more accurate description of the community in question. It seems that all the above factors work in tandem to guarantee that interlocutors achieve convergence with the addresser's speech.

Of relevance here is the theory of Speech Accommodation Theory (SAT) proposed by the social psychologist Howard Giles and associates. Giles (2001, as cited in Bell 2009: 992) defined accommodation as "the adjustment of one's speech or other communicative behaviours vis-à-vis the people with whom one is interacting". It is conceived as consisting of two major styles: divergence and convergence. Unlike in divergence, in convergence, it is attempted that social distance be reduced/minimized (Yule 1999). The direction of this convergence is seen to be from bottom to top; that is, it is done mostly by younger interlocutors to follow older ones, by females to adhere to males' conventions of speech and by the economically weak interlocutors to the wealthier interlocutors. In almost all these cases, the direction of the speech accommodation is from the less powerful to the more powerful. The degree of power, as stated before, is determined by factors such as age, sex, kinship and so forth. That is to say, younger, female, less socially and economically influential interlocutors are expected to synchronize their speech with that of the older, male and more socially and economically dominant individuals.

Another concept of significance and relevance to this discussion is Audience Design which stipulates that speakers primarily shift their style according to the audience the interlocutor engages in interaction with. It differs from the SAT in origin: while SAT originated from social psychology, Audience Design has its origins in sociolinguistics (Bell 2009). Therefore, the latter concept seems to be more relevant here as the current study is sociolinguistic in nature, too. Audience Design has been applied mostly in shifts in speech styles. The notion of Audience Design proves 
immediately and widely applicable in the Arab speech community in that it is most frequently observed that convergence, the most manifest form of Audience Design (Bell 2009), is also a very common practice in the Arab speech community under examination. This brings the discussion to and is reminiscent of the hierarchical nature of the Arab speech community: only in a community with dominant and widespread power relations, built around the concept of power, struggle and dominance, do individuals attempt to adjust their speech style to that of their addresser. Sociolinguistically speaking, it is seen that applying this concept yields interesting insights in the Arabic context: the existence of different ways of speaking, particularly with males' ways considered the norm, is a result of highly asymmetrical relations.

\subsection{Politeness, Impoliteness and Power}

Closely linked to the interlocutor relative power $(P)$, politeness is conceived as having two senses: a commonplace notion of politeness and a scientific conceptualization of politeness (Bataineh \& Bataineh 2006). It is also closely associated with social distance (D). Along with rank of imposition (R), these two factors, $D$ and $R$, are of considerable significance in theorizing and research on politeness (Brown \& Levinson 1987). When examining politeness, it is worthy of note that the issue of the masculine power is highly documented in the literature. Wardhaugh (2006: 331) holds that,

[m]en have more power and may be more assertive; women tend to be kept 'in their place' but aspire quite often to a different and 'better' place. Women therefore appear to be more conscious of uses of language which they associate with their 'betters' in society, that is, those they regard as being socially superior.

Power is most often compared and contrasted with solidarity. Johnstone (2008) maintains that whereas power deals with asymmetrical relations, solidarity is created in symmetrical relations. Taking into account Johnstone's view, we are led to the tentative conclusion that the highly hierarchical social structure of the Arab speech community 
has origins in its asymmetry of relations, asymmetric in the sense that Arab men and women simply are not equal in terms of their social roles. Our observations confirm this assumption, suggesting that women do not hold at all the same level and degree of power as men do which is evident in the way women speak (e.g., using lower voice, avoidance of answering back, frequent use of hedged language, more frequent use of euphemistic expressions as opposed to linguistic taboos, etc.).

\subsection{The Dynamics of Discoursal/Discursive Variables}

The above description of the Arab speech community confirms that this setting is multifarious. By participating in such a culturally and linguistically multifaceted setting, the interlocutor assumes that $s /$ he is fully cognizant of the dynamics described in the previous sections. The fundamental effect of religious affiliation and masculine power on the production, reproduction and legitimization of the male dominance over the female has already been documented in Arab settings (see, e.g., Al-Ali 2006). Bailey (2000) contends that language restricts individuals' identities in certain ways although it can be used to highlight one's freedom in other respects as well. In this regard, Bailey (2000) brings to attention the way language is utilized by Wilson, a Dominican American, to construct his identity by invoking his African-descent phenotype. Similar to Bailey's argument, the results of the current study revealed that the Arabic ethnocentric values, customs, decent and identity are the focus of attention in a good number of what Arabs call 'Abudhiahs'. These are four-line short pieces of poems recited by eloquent Arab poets in public ceremonies such as funeral rituals. Most of these poetic verses call toward bravery, gallantry and generosity and warn the hearers against cowardice, pusillanimity and parsimoniousness. Our observations clearly demonstrated that these verses are widely memorized and recited by a large of children, even as young as 6 and 7 years of age. There were observed gatherings of children during which those who knew the verses by heart recited them for others while other children listened closely and commended the reciters. It is based on these findings that the identity (re)construction in an Arab setting is to be understood in light of the sociocultural, sociolinguistic and sociological backgrounds shared by the community members. In sum, our evidence 
points to a historically, sociocultural, politically and linguistically constructed and shared attitudes, values and beliefs.

Considered together, the above-mentioned social and individual factors can be construed as interacting in mutual ways to create a social, 'collective' type of identity among the members of a CofP or a speech community. This brings the discussion to another theory in social psychology, the theory of social identity, which was first introduced by Henri Tajfel (1978, as cited in Holmes 1999). According to Holmes (1999), the notion of social identity defines individuals' social behavior in terms of their group affiliation and relationship interpretation. On this ground, the power of the male group can be attributed to their belonging to the dominant group which has been empowered throughout long historical, cultural and social development. On the other hand, the female gender is normally stereotyped by the male dominant group as feeble, lacking in power, both physical and mental, and consequently as unqualified to bear social responsibilities. The mutual dynamics of these variables are captured in Brown and Levinson's (1987) Politeness Theory which concerns itself with three major factors: D (social distance), $\mathrm{P}$ (power) and R (degree of imposition). It is seen that this theory is easily applicable to the analysis of Arab speech communities, warranting further attention and research.

The complexity of the Arab society is even greater when the role of the interlocutors' gender is invoked. In the Abudhiahs mentioned earlier in this paper, it is males who are mentioned in all of the verses recited. Rarely are women cited in these verses unless a submissive role is ascribed to them.

\section{Concluding Remarks}

The current sociolinguistic analysis reveals that the linguistic phenomena of power, solidarity, politeness and impoliteness are intertwined in interaction. What follows from the discussion provided in this study is that the Arabic society and consequently the interactions, linguistic and non-linguistic, therefrom are strictly hierarchical. The discussion clarifies that the role of kinship, age, the biological sex and 
its sociological equivalent, gender, ethnicity, religious affiliation, becomes unquestionably influential in such a multilayered setting. It also captured the gender inequalities produced, reproduced and practiced in this speech community. As Wardhaugh (2006) remarked, "Some forces in society are stronger than others and produce real effects, among them linguistic effects that have consequences for the lives we live" (p. 6). It seems that every use of language can be appraised in terms of context. Watts (2003) argued for conceptualizing (im)politeness as a social practice. These dynamics are far more complex than one expects them to be simply a correlation of certain linguistic forms and strategies with one gender or another. As Mills (2003: 239) argued in relation to the relation between gender and politeness, "the association of women with the use of tag-questions or with minimal responses, for example, is one which operates only at the level of stereotype".

It seems that most, if not all, of the practices that Arab members of the speech community in question are engaged in are attempts to construct and reconstruct a 'collective identity'. Although this is a tentative conclusion, it has some foothold in recent research. For instance, Suleiman (2003: 5) states that "collective identities are anchored in relation to such variables as genealogy, age, gender, sexuality, class, occupation, locality [...]". There arises, therefore, room for identity (re)construction.

Sociolinguistic investigations are extremely valuable in that they reveal to us hidden layers of linguistic practices which are embedded in social milieu. Future research might focus on the details of each of the above variables more closely and subsequently yield more illuminating insights. Future research can also be carried out on other language minorities whether in Iran or other countries. Further, the variables that were considered here such as gender, ethnicity, age, etc. were examined only broadly and therefore it is suggested that future research analyze each variable separately and in depth. 


\section{References}

AL-ALI, Mohammed Nahar (2006) "Religious affiliations and masculine power in Jordanian wedding invitation genre", Discourse \& Society, 17, 6, 691-714.

ANWAR, Etin (2004) "Public roles of women", in Richard. C. Martin (ed.), Encyclopedia of Islam and the Muslim world, USA: Macmillan Reference, 734-735.

ASSIRI, Mohammed (2012) "ana aasif jiddan yaa akhi": An intercultural study of illocutionary preferences and gender differences in Arabic apology", The Linguistics Journal, 6, 1, 235256.

AUstin, J. L. (1962) How to do things with words, Oxford: Calderon Press.

BAILEY, Benjamin (2000) "Language and negotiation of ethnic/racial identity among Dominican Americans", Language in Society, 29, 555-582.

BATAINeH, Ruba Fahmi \& Rula Fahmi BATAINEH (2006) "Apology strategies of Jordanian EFL university students", Journal of Pragmatics, 38, 1901-1927.

Beckner, C., R. Blythe, J. Bybee, M. H. Christiansen, W. Croft, N. C. Ellis, J. Holland, J. Ke, D. LARSEN-FreEmAn \& T. \& SChoenemanN (2009) "Language is a complex adaptive system: Position paper", in Nick C. Ellis \& Diane Larsen-Freeman (eds.), Language as a complex adaptive system, USA: Blackwell Publishing: 1-26.

BELL, Allan (2009) "Speech accommodation theory and audience design", in Jacob L. Mey (ed.) Concise encyclopedia of pragmatics, UK: Elsevier, 992-994.

Brown, Penelope \& Stephen C. LeVINSON (1987) Politeness: Some universals in language usage, Cambridge: Cambridge University Press.

CAMERON, Richard (2005) “Aging and gendering", Language in Society, 34, 23-61.

ChRISTMANn, Andreas (2009) The Qur'an, morality and critical reason: The essential Muhammad Shahrur, USA: Brill.

DAVIES, Bethan (2005) "Communities of practice: Legitimacy not choice", Journal of Sociolinguistics, 9, 4, 557-581.

DICKINSON, Paul (2013) "B/w U \& me": The functions of formulaic language in interactional discourse on Twitter", The Linguistics Journal, 7, 1, 7-38.

ECKERT, Penelope \& Étienne Wenger (2005) "What is the role of power in sociolinguistic variation?", Journal of Sociolinguistics, 9, 4, 582-589.

HOLMES, Janet (1999) "The Community of Practice: Theories and methodologies in language and gender research", Language in Society, 28, 173-183. 
http:// www.Britannica.com. Accessed on December 20, 2014.

http:// www.En.wikipedia.org. Accessed on December 20, 2014.

HYMES, Dell (2004) Ethnography, linguistics, narrative inequality: Toward an understanding of voice, London: Taylor \& Francis.

IRVING, J. T. (2009) "Speech and language community", in Jacob L. Mey (ed.) Concise encyclopedia of pragmatics, UK: Elsevier, 1020-1029.

JAFFE, Alexandra (2014) "Anthropological analysis in sociolinguistics", in Janet Holmes \& Kirk Hazen (eds.), Research methods in sociolinguistics, US: Wiley Blackwell, 213-229.

JOHNSTONE, Barbara (2008) Discourse analysis ( $2^{\text {nd }}$ ed.), USA: Blackwell Publishing.

LIDDICOAT, Anthony J. (2011) "Language teaching and learning from an intercultural perspective", in Eli Hinkel (ed.) Handbook of research in second language teaching and learning, New York: Routledge, 837-855.

MALINOWSKI, B. (1999 [1926]) “On Phatic Communion”, in Adam Jaworski \& Nikolas Coupland (eds.), The discourse reader, London and New York: Routledge, 302-305.

MERNISSI, Fatima (2005) "Beyond the veil: At play in the bed of the Prophet", in Daniel Martin Varisco (ed.), Islam obscured: The rhetoric of anthropological representation, New York: Palgrave Macmillan, 81-113.

Microsoft ${ }^{\circledR}$ Encarta ${ }^{\circledR}$ 2009. (C) 1993-2008 Microsoft Corporation. All rights reserved.

MILLS, Sara (2003) Gender and politeness, Cambridge: Cambridge University Press.

NIGOSIAN, Solomon A. (2004) Islam: its history, teaching and practices, USA: Indiana University Press.

PennyCOOK, Alastair (2009) "Critical applied linguistics", in Jacob L. Mey (ed.) Concise encyclopedia of pragmatics, UK: Elsevier Ltd., 158-165.

PILCHER, Jane \& Imelda WHELEHAN (2004) Fifty key concepts in gender studies, London: SAGE Publications.

SCHILLING-ESTES, Natalie (2004) "Constructing ethnicity in interaction, Journal of Sociolinguistics, 8, 2, 163-195.

SMART, Graham (2012) "Discourse-oriented ethnography", in James Paul Gee \& Michael Handford (eds.), The Routledge handbook of discourse analysis, London and New York: Routledge, 147-159.

SUlEIMAN, Yasir (2003) The Arabic language and national identity: A study in ideology, Edinburgh: Edinburgh University Press.

WARDHAUGH, Ronald (2006) An introduction to sociolinguistics, New York: Basil Blackwell Inc.

WATTS, Richard (2003) Politeness, Cambridge: Cambridge University Press. 
Dialectologia 23 (2019), 213-233.

ISSN: 2013-2247

WeISS, Gilbert \& Ruth WODAK (2003) Critical discourse analysis, New York: Palgrave Macmillan Ltd.

YULE, George (1999) The study of language, Cambridge: Cambridge University Press. 